Prepared in cooperation with the Department of the Navy, Naval Facilities Engineering Command, Northwest

\title{
Analysis of Groundwater Response to Tidal Fluctuations, Operable Unit 2, Area 8, Naval Base Kitsap, Keyport, Washington
}

Open-File Report 2018-1082 



\section{Analysis of Groundwater Response to Tidal Fluctuations, Operable Unit 2, Area 8, Naval Base Kitsap, Keyport, Washington}

By Chad C. Opatz and Richard S. Dinicola

Prepared in cooperation with the Department of the Navy, Naval Facilities Engineering Command, Northwest

Open-File Report 2018-1082 


\title{
U.S. Department of the Interior \\ RYAN K. ZINKE, Secretary
}

\section{U.S. Geological Survey James F. Reilly II, Director}

U.S. Geological Survey, Reston, Virginia: 2018

\begin{abstract}
For more information on the USGS-the Federal source for science about the Earth, its natural and living resources, natural hazards, and the environment-visit https://www.usgs.gov/ or call 1-888-ASK-USGS (1-888-275-8747).
\end{abstract}

For an overview of USGS information products, including maps, imagery, and publications, visit https://store.usgs.gov/.

Any use of trade, firm, or product names is for descriptive purposes only and does not imply endorsement by the U.S. Government.

Although this information product, for the most part, is in the public domain, it also may contain copyrighted materials as noted in the text. Permission to reproduce copyrighted items must be secured from the copyright owner.

Suggested citation:

Opatz, C.C., and Dinicola, R.S., 2018, Analysis of groundwater response to tidal fluctuations, Operable Unit 2, Area 8, Naval Base Kitsap, Keyport, Washington: U.S. Geological Survey Open-File Report 2018-1082, 20 p., https://doi.org/10.3133/ofr20181082.

ISSN 2331-1258 (online) 


\section{Contents}

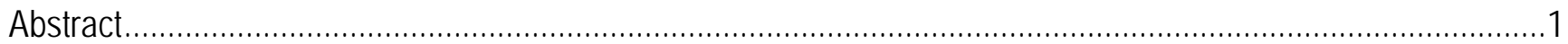

Introduction

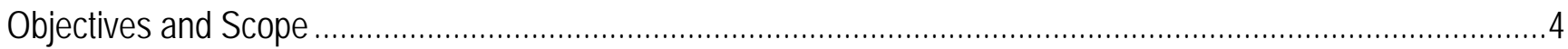

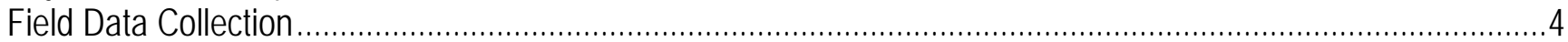

Conductivity, Temperature, and Depth Sensor Deployment and Vertical Water-Quality Profiling .....................5

Conductivity, Temperature, and Depth Sensor Retrieval and Sonde Measurements ........................................7

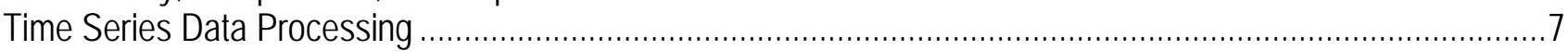

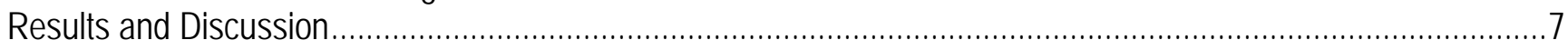

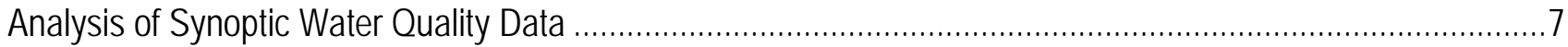

Analysis of Time Series Water Level and Specific Conductance Data ...........................................................

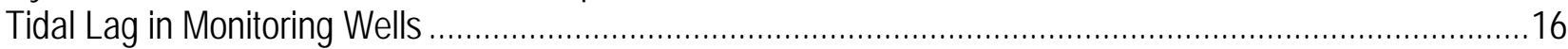

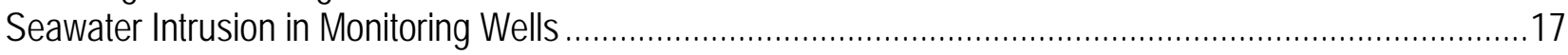

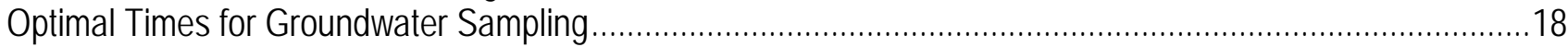

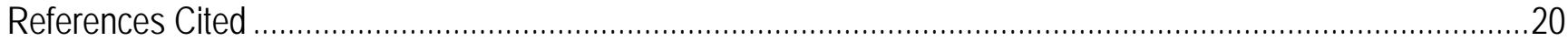

\section{Figures}

Figure 1. Locations of monitoring wells at Operable Unit 2, Area 8, Naval Base Kitsap, Keyport, Washington......3 Figure 2. Time series of groundwater level, tidal level, and specific conductance of groundwater in shallow well MW8-8, Operable Unit 2, Area 8, Naval Base Kitsap, Keyport, Washington, October 24November 17, 2017

Figure 3. Time series of groundwater level, tidal level, and specific conductance of groundwater in shallow well MW8-9, Operable Unit 2, Area 8, Naval Base Kitsap, Keyport, Washington, October 24November 17, 2017

Figure 4. Time series of groundwater level, tidal level, and specific conductance of groundwater in shallow well MW8-11, Operable Unit 2, Area 8, Naval Base Kitsap, Keyport, Washington, October 24November 17, 2017

Figure 5. Time series of groundwater level, tidal level, and specific conductance of groundwater in shallow well MW8-12, Operable Unite 2, Area 8, Naval Base Kitsap, Keyport, Washington, October 24November 17, 2017

Figure 6. Time series of groundwater level, tidal level, and specific conductance of groundwater in the deep well MW8-16, Operable Unit 2, Area 8, Naval Base Kitsap, Keyport, Washington, October 24November 17, 2017

Figure 7. Differences between tides measured at the study site and tides predicted for nearby tidal reporting NOAA Station 9445719, Operable Unit 2, Area 8, Naval Base Kitsap, Keyport, Washington, October 24November 17, 2017

Figure 8. Barometric pressure and wind speeds measured at Seattle (National Weather Service Seattle Coop Station 9447130), October 24-November 17, 2017

Figure 9. Water levels in a landward (MW8-8) and a seaward (MW8-9) well indicating direction of hydraulic gradient at Operable Unit 2, Area 8, Naval Base Kitsap, Keyport, Washington, October 24November 17, 2017 


\section{Tables}

Table 1. Characteristics of wells at Operable Unit 2, Area 8, Naval Base Kitsap, Keyport, Washington

Table 2. Depth-to-water measurements made during deployment and retrieval of the conductivitytemperature-depth sensors (CTDs) and a pressure logger in six Area 8 monitoring wells and in Port Orchard Bay, Operable Unit 2, Naval Base Kitsap, Keyport, Washington.

Table 3. Measurements made by conductivity-temperature-depth sensors (CTDs) and a multi-parameter sonde during deployment and retrieval of the CTDs at Operable Unit 2, Area 8, Naval Base Kitsap, Keyport, Washington.....

Table 4. Vertical water-quality profiles measured with a multi-parameter sonde at Area 8 wells prior to deployment on October 24, 2017, at Operable Unit 2, Naval Base Kitsap, Keyport, Washington.

Table 5. Ranges of lag times between the occurrence of a minimum groundwater level elevation in a monitoring well and the preceding low tide calculated from data collected October 28-November 10, 2018, at Operable Unit 2, Area 8, Naval Base Kitsap, Keyport, Washington

\section{Conversion Factors}

U.S. customary units to International System of Units

\begin{tabular}{ccc}
\hline Multiply & By & To obtain \\
\hline & Length & \\
\hline foot (ft.) & 0.3048 & meter (m) \\
\hline
\end{tabular}

Temperature in degrees Celsius $\left({ }^{\circ} \mathrm{C}\right)$ may be converted to degrees Fahrenheit $\left({ }^{\circ} \mathrm{F}\right)$ as follows:

$$
{ }^{\circ} \mathrm{F}=\left(1.8 \times{ }^{\circ} \mathrm{C}\right)+32 \text {. }
$$

\section{Datums}

Vertical coordinate information is referenced to the North American Vertical Datum of 1988 (NAVD 88). Horizontal coordinate information is referenced to the North American Datum of 1927 (NAD 27).

Elevation, as used in this report, refers to distance above the vertical datum.

\section{Supplemental Information}

Specific conductance is given in microsiemens per centimeter at 25 degrees Celsius $\left(\mu \mathrm{S} / \mathrm{cm}\right.$ at $\left.25^{\circ} \mathrm{C}\right)$.

\section{Abbreviations}

$\begin{array}{ll}\text { MLLW } & \text { mean low-low water } \\ \text { NBK } & \text { Naval Base Kitsap } \\ \text { CTD } & \text { conductivity, temperature, and depth sensor } \\ \text { TOC } & \text { top of casing }\end{array}$




\title{
Analysis of Groundwater Response to Tidal Fluctuations, Operable Unit 2, Area 8, Naval Base Kitsap, Keyport, Washington
}

\author{
By Chad C. Opatz and Richard S. Dinicola
}

\begin{abstract}
Operable Unit 2, Area 8, at Naval Base Kitsap, Keyport is the site of a former chrome-plating facility that released metals (primarily chromium and cadmium), chlorinated volatile organic compounds, and petroleum compounds into the local environment. To ensure long-term protectiveness, as stipulated in the Fourth Five-Year Review for the site, Naval Facilities Engineering Command Northwest collaborated with the U.S. Environmental Protection Agency, the Washington State Department of Ecology, and the Suquamish Tribe, to collect data to monitor the contamination left in place and to ensure the site does not pose a risk to human health or the environment. To support these efforts, refined information was needed on the interaction of fresh groundwater with seawater in response to the up-to 13-ft tidal fluctuations at this nearshore site adjacent to Port Orchard Bay. The information was analyzed to meet the primary objective of this investigation, which was to determine the optimal time during the semi-diurnal and the neap-spring tidal cycles to sample groundwater for freshwater contaminants in Area 8 monitoring wells.

Groundwater levels and specific conductance in five monitoring wells, along with marine waterlevels (tidal levels) in Port Orchard Bay, were monitored every 15 minutes during a 3-week duration to determine how nearshore groundwater responds to tidal forcing. Time series data were collected from October 24, 2017, to November 16, 2017, a period that included neap and spring tides. Vertical profiles of specific conductance were also measured once in the screened interval of each well prior to instrument deployment to determine if a freshwater/saltwater interface was present in the well during that particular time.

The vertical profiles of specific conductance were measured only one time during an ebbing tide at approximately the top, middle, and bottom of the saturated thickness within the screened interval of each well. The landward-most well, MW8-8, was completely freshwater, while one of the most seaward wells, MW8-9, was completely saline. A distinct saltwater interface was measured in the three other shallow wells (MW8-11, MW8-12, and MW8-14), with the topmost groundwater occurring fresh underlain by higher conductivity water.

Lag times between minimum spring-tide level and minimum groundwater levels in wells ranged from about 2 to 4.5 hours in the less-than 20 -ft deep wells screened across the water table, and was about 7 hours for the single 48-ft deep well screened below the water table. Those lag times were surprisingly long considering the wells are all located within 200-ft of the shoreline and the local geology is largely coarse-grained glacial outwash deposits. Various manmade subsurface features, such as slurry walls and backfilled excavations, likely influence and confuse the connectivity between seawater and groundwater.
\end{abstract}


The specific-conductance time-series data showed clear evidence of substantial saltwater intrusion into the screened intervals of most shallow wells. Unexpectedly, the intrusion was associated with the neap part of the tidal cycle around November 13-16, when relatively low barometric pressure and high southerly winds led to the highest high and low tides measured during the monitoring period. The data consistently indicated that the groundwater had the lowest specific conductance (was least mixed with seawater) during the prior neap tides around October 30, the same period when the shallow groundwater levels were lowest. Although the specific conductance response is somewhat different between wells, the data do suggest that it is the heights of the actual high-high and low-low tides, regardless of whether or not they occur during the neap or spring part of the cycle, that allows seawater intrusion into the nearshore aquifer at Area 8.

With all the data taken into consideration, the optimal time for sampling the shallow monitoring wells at Area 8 would be centered on a 2-5-hour period following the predicted low-low tide during neap tide, with due consideration of local atmospheric pressure and wind conditions that have the potential to generate tides that can be substantially higher than those predicted from lunar-solar tidal forces. The optimal time for sampling the deeper monitoring wells at Area 8 would be during the 6-8hour period following a predicted low-low tide, also during the neap tide part of the tidal cycle. The specific time window to sample each well following a low tide can be found in table 5 . Those periods are when groundwater in the wells is most fresh and least diluted by seawater intrusion. In addition to timing, consideration should be given to collecting undisturbed samples from the top of the screened interval (or top of the water table if below the top of the interval) to best characterize contaminant concentrations in freshwater. A downhole conductivity probe could be used to identify the saltwater interface, above which would be the ideal depth for sampling.

\section{Introduction}

Operable Unit (OU) 2, Area 8, at Naval Base Kitsap (NBK) Keyport (fig. 1) is the site of an inactive chrome-plating facility where metals (primarily chromium and cadmium), chlorinated volatile organic compounds, and petroleum compounds were released into the local environment (U.S. Navy, U.S. Environmental Protection Agency, and Washington State Department of Ecology, 1994). As stipulated in the Naval Facilities Engineering Command Northwest (2015), in conjunction with Environmental Protection Agency, Washington State Department of Ecology, and the Suquamish Tribe, is charged with collecting necessary data to monitor the contamination left in place to ensure the site does not pose a risk to human health or the environment, and to ensure future long-term protectiveness. To support these efforts, refined information was needed on the interaction of fresh groundwater with seawater in response to tidal fluctuations at this nearshore site adjacent to Port Orchard Bay, given the \pm 13 -ft tidal fluctuations in Port Orchard Bay. The results of this investigation can be used to ensure that groundwater monitoring is done at an optimum time to assess contaminant concentrations in groundwater that originated at Area 8, with the optimal time presumed to be when groundwater in a well is the most fresh and the least mixed with seawater. This knowledge will ultimately allow site managers to better evaluate contaminant fate and transport, and risks to human health and (or) the environment. 


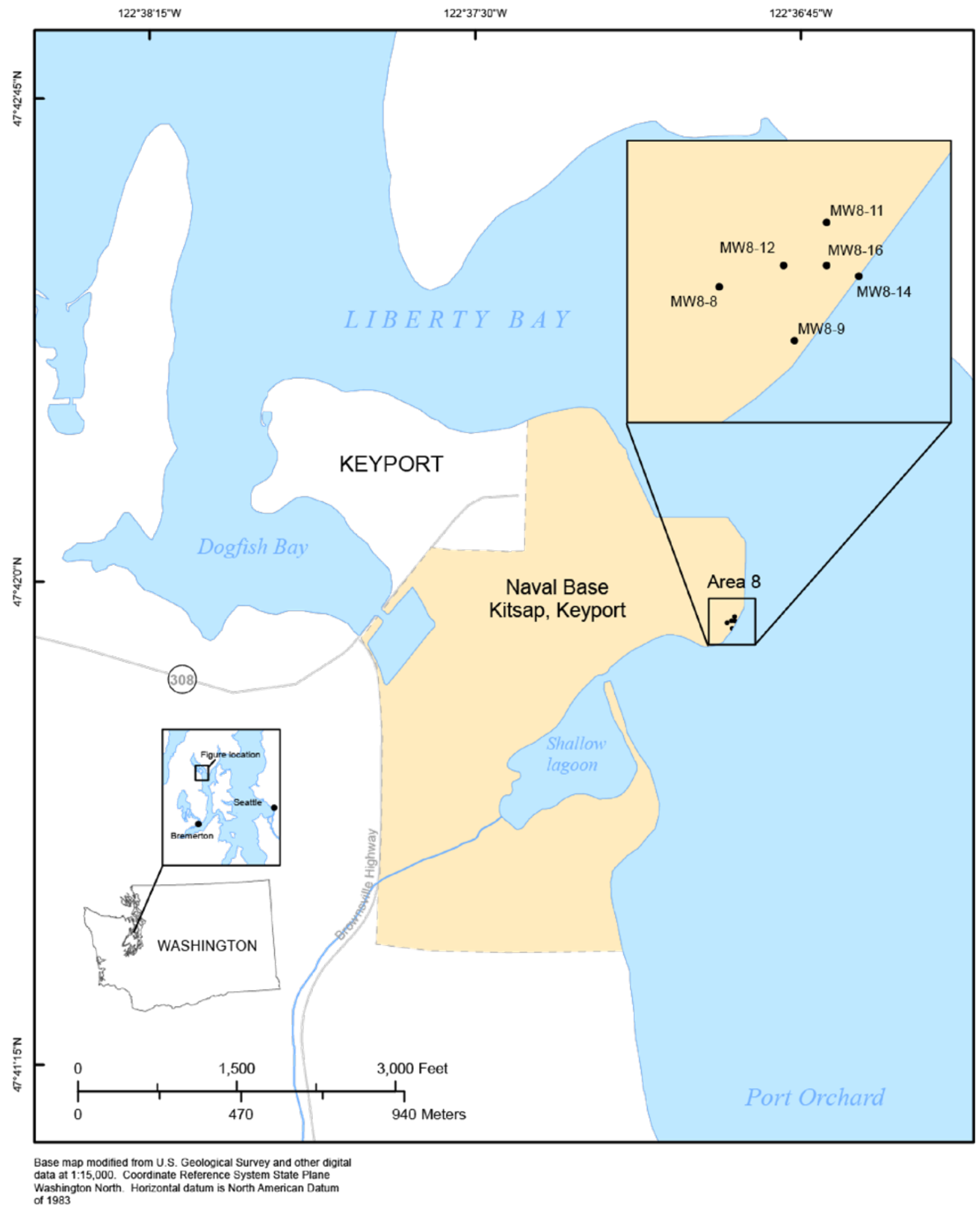

Figure 1. Locations of monitoring wells at Operable Unit 2, Area 8, Naval Base Kitsap, Keyport, Washington. The tidal monitoring site was approximately 200 feet to the east of well MW8-14. 


\section{Objectives and Scope}

The overall objective of this report is to describe the data collection and analysis that has led to a better understanding of nearshore groundwater-seawater interactions at Area 8 as driven by the up to 13$\mathrm{ft}$ tidal fluctuations in the adjacent Port Orchard Bay. The specific objective of this project was to determine the optimal time during the semi-diurnal and the neap-spring tidal cycles to sample groundwater for freshwater contaminants in Area 8 monitoring wells. To achieve that objective, we calculated tidal lag times for selected Area 8 nearshore monitoring wells and determined which times during the tidal cycle the proportion of fresh groundwater relative to seawater in the wells is the largest.

The scope of this investigation included the collection of continuous conductivity, temperature, and depth (CTD) data in six existing monitoring wells, and in nearby Port Orchard Bay over at least a 2week monitoring period that included a complete spring (maximum tidal change) to neap (minimum tidal change) cycle. The scope of the data analyses included the calculation of tidal lag times, defined as the time between when a maximum or minimum tide occurred and when a subsequent maximum or minimum water level occurred in the nearshore wells, and the identification of when, during both the semi-diurnal cycle and the neap-spring tidal cycle, the measured wells have the greatest proportion of fresh groundwater.

\section{Field Data Collection}

On October 24, 2017, a U.S. Geological Survey field team deployed vented ConductivityTemperature-Depth sensors (hereafter referred to as CTDs) in six Area 8 monitoring wells (table 1), and a non-vented water-level data logger in Port Orchard Bay. The CTDs were operational from October 24 to November 16, 2017. The predicted tides for that period at nearby Poulsbo, Washington (NOAA Station 9445719) included the moderate tidal-range neap tides around October 30 and November 13, and the larger tidal-range spring tides around October 23 and November 6.

Table 1. Characteristics of wells at Operable Unit 2, Area 8, Naval Base Kitsap, Keyport, Washington.

[Measuring point elevation: Feet above North American Vertical Datum of 1988 as measured from top of casing. Screened interval: Feet below top of casing]

\begin{tabular}{lccc}
\hline $\begin{array}{c}\text { Local well } \\
\text { identifier }\end{array}$ & Measuring point elevation & Screened interval & Comments \\
\hline MW8-8 & 12.5 & $4.5-19.5$ & Monitored \\
MW8-9 & 11.93 & $5-20$ & Monitored \\
MW8-11 & 12.4 & $7-17$ & Monitored \\
MW8-12 & 11.95 & $7-17$ & Monitored \\
MW8-14 & 12.14 & $7-17$ & Sensor deployed but failed to log \\
MW8-16 & 12.62 & $42.5-47.5$ & Monitored \\
\hline
\end{tabular}


All sensors were lab-calibrated and checked for accuracy prior to deployment, including threepoint calibration checks on the CTDs using 250, 12,890 and 50,000 $\mu \mathrm{S} / \mathrm{cm}$ specific-conductance standards. A multi-parameter sonde equipped with sensors for measuring $\mathrm{pH}$, dissolved oxygen, temperature, and specific conductance was also lab calibrated and used to confirm the CTD measurements and to measure a synoptic vertical profile of water-quality in the screened intervals of the wells.

\section{Conductivity, Temperature, and Depth Sensor Deployment and Vertical Water-Quality Profiling}

All wells were accessed, and depth-to-water measurements were recorded (table 2). A vertical water-quality profile consisting of points at the top, middle, and bottom of the water column within each well-screen interval was measured using the multi-parameter sonde immediately prior to CTD deployment. The tide was ebbing at the time from about 8 to $10 \mathrm{ft}$ above mean low-low water (MLLW). The CTDs were then lowered and secured at elevations approximately mid-depth of the well-screen interval (table 3). Because of the relatively rapid tidally induced water-level changes in the monitoring wells, a final manual depth-to-water measurement was recorded immediately before the first scheduled water-level measurement recorded by deployed CTD in each well. Each CTD was programmed to record data at 15-minute intervals.

Table 2. Depth-to-water measurements made during deployment and retrieval of the conductivity-temperaturedepth sensors (CTDs) and a pressure logger in six Area 8 monitoring wells and in Port Orchard Bay, Operable Unit 2, Naval Base Kitsap, Keyport, Washington.

[Elevation shown in feet above North American Vertical Datum of 1988. Depth to water was measured immediately before deploying a CTD in a well, and again at the time the CTD was programmed to begin sampling on October 26, 2017. PST, Pacific Standard Time]

\begin{tabular}{lrcc}
\hline Well identifier & Date & $\begin{array}{c}\text { Time of } \\
\text { measurement }\end{array}$ & $\begin{array}{c}\text { Water level } \\
\text { elevation }\end{array}$ \\
\hline WM8-8 & $10-24-17$ & 1000 & 3.00 \\
& $10-24-17$ & 1045 & 3.09 \\
MW8-9 & $11-16-17$ & 1109 & 8.38 \\
& $10-24-17$ & 1015 & 3.29 \\
& $10-24-17$ & 1111 & 3.19 \\
MW8-11 & $11-16-17$ & 0953 & 8.50 \\
& $10-24-17$ & 1008 & 2.66 \\
& $10-24-17$ & 1213 & 2.81 \\
MW8-12 & $11-16-17$ & 1031 & 8.80 \\
& $10-24-17$ & 1002 & 2.43 \\
& $10-24-17$ & 1136 & 2.70 \\
MW8-14 & $11-16-17$ & 1046 & 7.95 \\
& $10-24-17$ & 1010 & 3.40 \\
& $10-24-17$ & 1315 & 2.45 \\
MW8-16 & $11-16-17$ & 1004 & 9.43 \\
& $10-24-17$ & 1012 & 3.95 \\
& $10-24-17$ & 1248 & 3.12 \\
& $11-16-17$ & 1015 & 9.53 \\
\hline
\end{tabular}


Table 3. Measurements made by conductivity-temperature-depth sensors (CTDs) and a multi-parameter sonde during deployment and retrieval of the CTDs at Operable Unit 2, Area 8, Naval Base Kitsap, Keyport, Washington.

[Depth: Feet below top of casing. Abbreviations: PST, Pacific Standard Time; ${ }^{\circ} \mathrm{C}$, degrees Celsius; $\mu \mathrm{S} / \mathrm{cm}$, microsiemen per centimeter at 25 degrees Celsius; mg/L, milligram per liter; -, data missing]

\begin{tabular}{|c|c|c|c|c|c|c|c|c|c|c|}
\hline \multirow[b]{2}{*}{$\begin{array}{c}\text { Well } \\
\text { identifier }\end{array}$} & \multirow[b]{2}{*}{ Date } & \multirow[b]{2}{*}{$\begin{array}{l}\text { Time of } \\
\text { measurement } \\
\text { (PST) }\end{array}$} & \multicolumn{3}{|c|}{ CTD measurements } & \multicolumn{5}{|c|}{ Sonde measurements } \\
\hline & & & Depth & $\begin{array}{c}\text { Temperature } \\
\left({ }^{\circ} \mathrm{C}\right)\end{array}$ & $\begin{array}{c}\text { Specific } \\
\text { conductance } \\
(\mu \mathrm{S} / \mathrm{cm})\end{array}$ & Depth & $\begin{array}{c}\text { Temperature } \\
\left({ }^{\circ} \mathrm{C}\right)\end{array}$ & $\begin{array}{c}\text { Specific } \\
\text { conductance } \\
(\mu \mathrm{S} / \mathrm{cm})\end{array}$ & $\mathrm{pH}$ & $\begin{array}{c}\text { Dissolved } \\
\text { oxygen } \\
\text { (mg/L) }\end{array}$ \\
\hline \multirow[t]{2}{*}{ MW8-8 } & 10-24-2017 & 1045 & 12.76 & 17.91 & 215 & 13.00 & 17.26 & 272 & 6.66 & 7.36 \\
\hline & 11-16-2017 & 1115 & 12.76 & 16.96 & 1,210 & 12.76 & 15.47 & 1,030 & 7.67 & 4.65 \\
\hline \multirow[t]{2}{*}{ MW8-9 } & $10-24-2017$ & 1111 & 13.20 & 17.01 & 35,200 & 12.50 & 16.05 & 35,300 & 6.74 & 6.82 \\
\hline & 11-16-2017 & 1000 & 13.20 & 14.00 & 38,500 & 13.20 & 14.20 & 35,500 & 7.16 & 1.38 \\
\hline \multirow[t]{2}{*}{ MW8-12 } & $10-24-2017$ & 1136 & 13.19 & 18.68 & 7,420 & 11.50 & 17.76 & 8,200 & 7.17 & 9.09 \\
\hline & 11-16-2017 & 1045 & 13.19 & 17.00 & 18,200 & 13.19 & 15.68 & 14,300 & 7.53 & 2.90 \\
\hline \multirow[t]{2}{*}{ MW8-11 } & $10-24-2017$ & 1213 & 13.19 & - & - & 11.50 & 18.55 & 28300 & 6.70 & 8.71 \\
\hline & 11-16-2017 & 1030 & 13.19 & 17.65 & 33,800 & 13.19 & 16.37 & 33,400 & 7.10 & 2.65 \\
\hline \multirow[t]{2}{*}{ MW8-14 } & $10-24-2017$ & 1315 & 13.84 & 16.76 & 44,600 & 10.00 & 16.05 & 44,500 & 7.80 & 9.73 \\
\hline & 11-16-2017 & 1000 & 13.84 & - & - & 13.84 & 12.38 & 41,200 & 7.80 & 2.28 \\
\hline \multirow[t]{2}{*}{ MW8-16 } & $10-24-2017$ & 1248 & 45.00 & 14.88 & 17,700 & 45.00 & 14.19 & 17,500 & 6.88 & 3.11 \\
\hline & 11-16-2017 & 1015 & 45.00 & 14.26 & 18,800 & 45.00 & 14.09 & 18,700 & 7.21 & 0.18 \\
\hline
\end{tabular}


A water-level data logger was deployed in the marine water approximately 200 feet offshore to measure tidal levels. The transducer was anchored in place at a fixed location on the marine floor, with a buoy attached to the anchor to facilitate retrieval. The transducer was deployed at a time (1453 Pacific Standard Time) and location when the marine water depth was 8.5-ft, a depth that ensured the transducer would remain submerged at the predicted lowest tide during the deployment. The predicted tide at that time for the nearest reporting site at Poulsbo (NOAA Station 9445719) was about $6.6 \mathrm{ft}$. above MLLW. Because the transducer was non-vented, a barometric pressure data logger was deployed onshore in the immediate area to collect pressure data used to correct non-vented marine water level data.

\section{Conductivity, Temperature, and Depth Sensor Retrieval and Sonde Measurements}

On November 16, 2017, a U.S. Geological Survey field team retrieved CTDs in six monitoring well and a water level data logger in Port Orchard Bay. All wells were accessed and depth-to-water measurements were recorded prior to the final 15-minute CTD measurement (table 1). Immediately after CTD retrieval, the multi-parameter sonde was lowered to the CTD measurement elevation in each well to measure water quality. It is likely that CTD retrieval agitated the water column in the well, so an exact match between CTD and sonde measurements was not expected.

\section{Time Series Data Processing}

The 15-minute time series data from the CTDs were downloaded in the field. Five CTDs were running and recording when retrieved; the CTD in well MW8-14 failed to initiate measuring so no 15minute CTD data were available at that site. Time series groundwater-level data were recorded with an arbitrary reference and corrected to elevations based on the NAVD88 geodetic datum using depth-towater values measured from a known elevation point at the top of casing at each well. Marine timeseries water level data measured with the non-vented pressure transducer were adjusted for changes in atmospheric pressure by subtracting the measured atmospheric (barometric) pressure from the marine pressure transducer measurement for each 15-minute value, with due consideration of units. To facilitate comparison to groundwater levels, the barometric pressure-adjusted marine water levels were adjusted by an estimated offset (-5.66) that approximately converted to the NAVD88 geodetic datum. The elevation of the marine pressure transducer was not surveyed, but the approximate elevation (referenced to the MLLW tidal datum) was estimated by assuming that the actual high and low tides during the first 3 days of deployment were equal to those predicted from the nearby Poulsbo tide station (NOAA Station 9445719).

\section{Results and Discussion}

\section{Analysis of Synoptic Water Quality Data}

Water-quality measurements made by the CTDs and the multi-parameter sonde during deployment and retrieval of the CTDs were similar (table 3). Some variation between the two data sets was expected due to slightly different measurement elevations on October 24 when the sonde could only be lowered to just above the CTD, and due to agitated well water when the sonde measurements followed CTD retrieval on November 16. 
The vertical water-quality profile data indicated variation across the saturated screened interval prior to data logger deployment on October 24 (table 4). The tide was ebbing from about 2 to $4 \mathrm{ft}$ (above NAVD88) when the profiles were measured. During this period following spring tides on October 23, groundwater in the most landward well MW8-8 was fresh across the entire screened interval with specific conductance ranging from 230 to $315 \mu \mathrm{S} / \mathrm{cm}$. In contrast, groundwater in the most seaward well MW8-9 was brackish across the entire screened interval with specific conductance ranging from 32,700 to $35,400 \mu \mathrm{S} / \mathrm{cm}$. Sharp salt-water interfaces were measured in the three other shallow wells MW8-11, MW8-12, and MW8-14, with specific conductance at the top of the screened interval ranging from 53 to $300 \mu \mathrm{S} / \mathrm{cm}$, underlain by more brackish water with specific conductance ranging from 8,200 to 44,600 $\mu \mathrm{S} / \mathrm{cm}$. A vertical profile was not measured in the relatively deep well MW8-16 that is screened about 45-ft below the water table, but the water was brackish (specific conductance 17,400 $\mu \mathrm{S} / \mathrm{cm}$ ). The conversion from specific conductance to salinity cannot be made precisely without additional data, but ambient Puget Sound water with specific conductance of about 45,000 $\mu \mathrm{S} / \mathrm{cm}$ would have a salinity of about 29 parts per thousand, and brackish water with a specific conductance of about 5,000 $\mu \mathrm{S} / \mathrm{cm}$ would have a salinity of about 3 parts per thousand.

Table 4. Vertical water-quality profiles measured with a multi-parameter sonde at Area 8 wells prior to deployment on October 24, 2017, at Operable Unit 2, Naval Base Kitsap, Keyport, Washington.

[Measurement time: PST, Pacific Standard Time. Abbreviations: ft below TOC, feet below top of casing; mg/L, milligram per liter; ${ }^{\circ} \mathrm{C}$, degrees Celsius; $\mu \mathrm{S} / \mathrm{cm}$, microsiemen per centimeter at $25^{\circ} \mathrm{C}$ ]

\begin{tabular}{cccccc}
\hline $\begin{array}{c}\text { Well } \\
\text { identification }\end{array}$ & $\begin{array}{c}\text { Measurement } \\
\text { Depth } \\
\text { (ft below TOC) }\end{array}$ & pH & $\begin{array}{c}\text { Dissolved } \\
\text { oxygen } \\
(\mathbf{m g} / \mathbf{L})\end{array}$ & $\begin{array}{c}\text { Temperature } \\
\left({ }^{\circ} \mathrm{C}\right)\end{array}$ & $\begin{array}{c}\text { Specific } \\
\text { conductance } \\
(\boldsymbol{\mu} \text { S/cm })\end{array}$ \\
\hline MW8-8 & 7 & 6.64 & 7.98 & 17.77 & 230 \\
MW8-9 & 13 & 6.66 & 7.36 & 17.26 & 272 \\
& 17 & 6.67 & 7.03 & 17.07 & 315 \\
MW8-11 & 7 & 6.84 & 7.29 & 16.34 & 32700 \\
& 12.5 & 6.74 & 6.82 & 16.05 & 35300 \\
MW8-12 & 17 & 6.62 & 7.24 & 15.87 & 35400 \\
& 8.5 & 6.76 & 10.63 & 18.62 & 192 \\
& 11.5 & 6.70 & 8.71 & 18.55 & 28300 \\
MW8-14 & 15 & 6.70 & 8.46 & 18.03 & 36800 \\
& 11.5 & 7.36 & 10.83 & 17.91 & 53 \\
& 15 & 7.17 & 9.09 & 17.76 & 8200 \\
MW8-16 & 6.5 & 7.07 & 8.59 & 17.47 & 11900 \\
& 10 & 7.80 & 12.19 & 16.15 & 300 \\
\hline
\end{tabular}


Overall, the vertical profile data indicate that the freshwater-saltwater interface is at times within the screened interval of at least three of the wells. Thus, when sampling for contaminants in the wells, consideration should be given to collecting undisturbed samples from the top of the screened interval (or top of the water table if below the top of the interval) to best characterize contaminant concentrations in freshwater.

\section{Analysis of Time Series Water Level and Specific Conductance Data}

Time-series plots of groundwater levels, tidal level, and groundwater specific conductance are shown in figures 3-7 for the five wells where CTD data collection was successful. Groundwater levels fluctuated semi-diurnally in concert with, but attenuated in time and magnitude with, the semi-diurnal tides the lowest groundwater levels measured in all shallow wells were associated with the neap tides around October 30, rather than the spring tides around November 6 when the tidal levels were lowest. The highest groundwater levels measured did not coincide with the highest predicted tides that were slated to occur during the November 7 spring tides; they instead occurred November 13-16 when the actual tides were 2-3 ft higher than those predicted (fig. 8). Thus, both the lowest and the highest groundwater levels were measured during two different neap tides, while the exceptionally low-lows or high-highs associated with spring tides did not coincide with the lowest or highest groundwater levels.

The cause for the different response of groundwater to the two neap tide cycles is the exceptionally high tide measured (but not predicted) November 13-16. These high tides were likely due to relatively low atmospheric pressure and high southerly winds in the vicinity during that period (fig. 9). These local weather conditions appeared to have had a greater influence on tidal heights and seawater-freshwater interactions at the site than did lunar and solar conditions that are reflected by the predicted tide. 


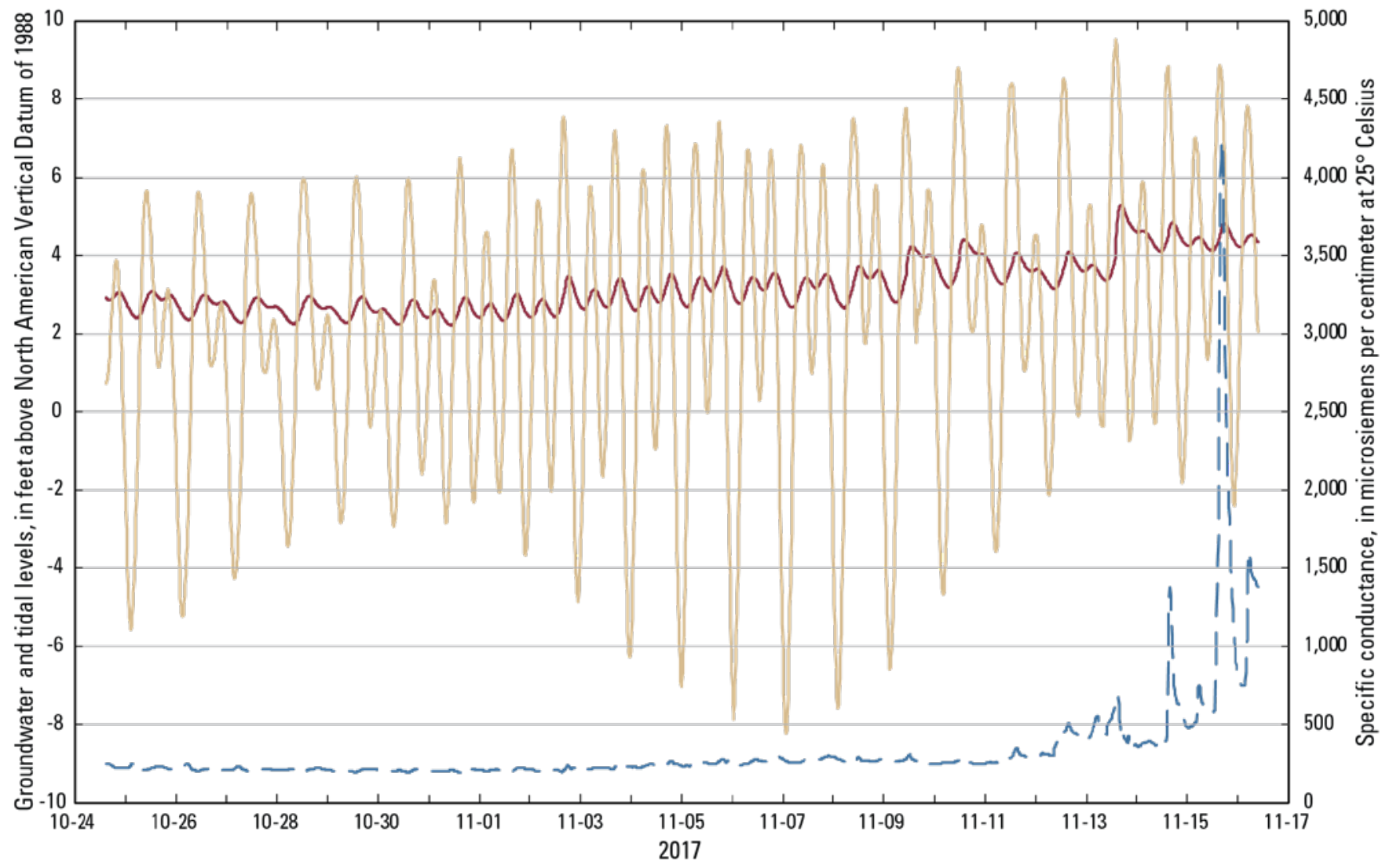

EXPLANATION

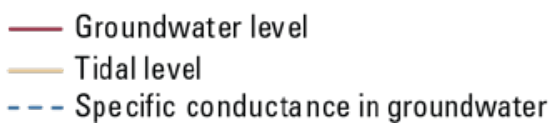

Figure 2. Time series of groundwater level, tidal level, and specific conductance of groundwater in shallow well MW8-8, Operable Unit 2, Area 8, Naval Base Kitsap, Keyport, Washington, October 24-November 17, 2017. 


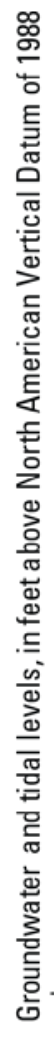

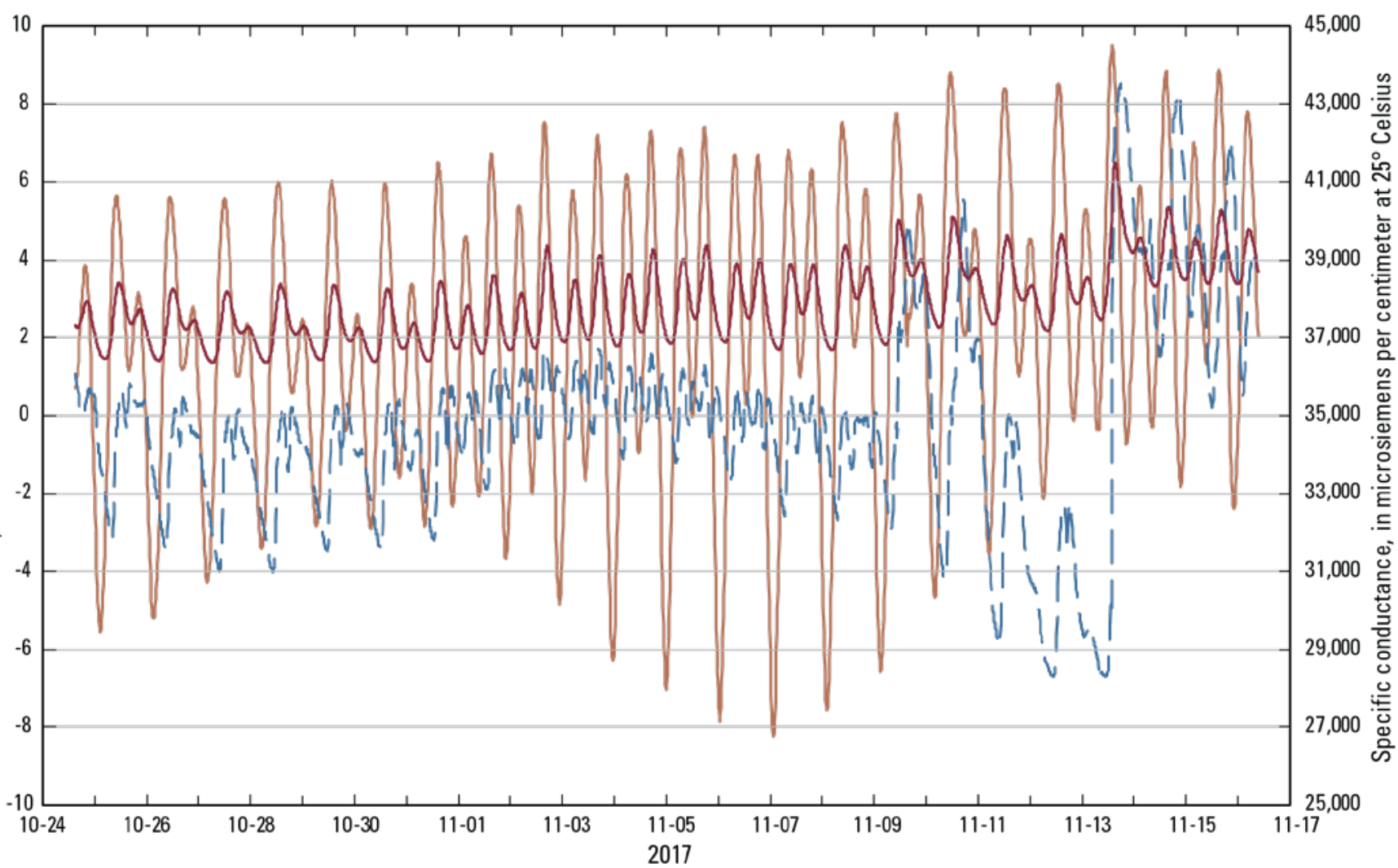

EXPLANATION

-Tidal level

-Groundwater level

---Groundwater specific conductance

Figure 3. Time series of groundwater level, tidal level, and specific conductance of groundwater in shallow well MW8-9, Operable Unit 2, Area 8, Naval Base Kitsap, Keyport, Washington, October 24-November 17, 2017. 


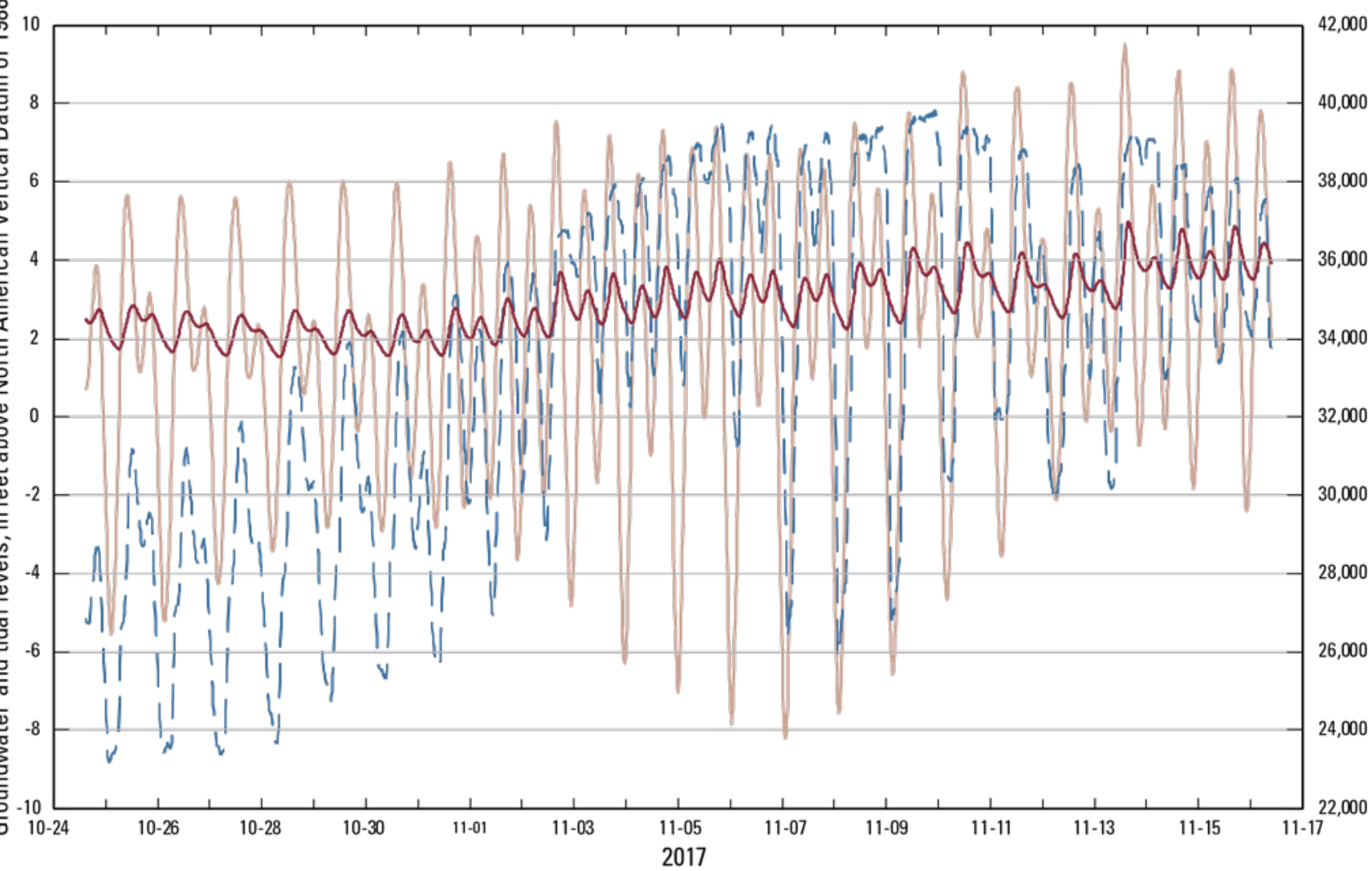
42,000

EXPLANATION

- Tidal level

- Groundwater level

- - - Groundwater specific conductance

Figure 4. Time series of groundwater level, tidal level, and specific conductance of groundwater in shallow well MW8-11, Operable Unit 2, Area 8, Naval Base Kitsap, Keyport, Washington, October 24-November 17, 2017. 
œ্

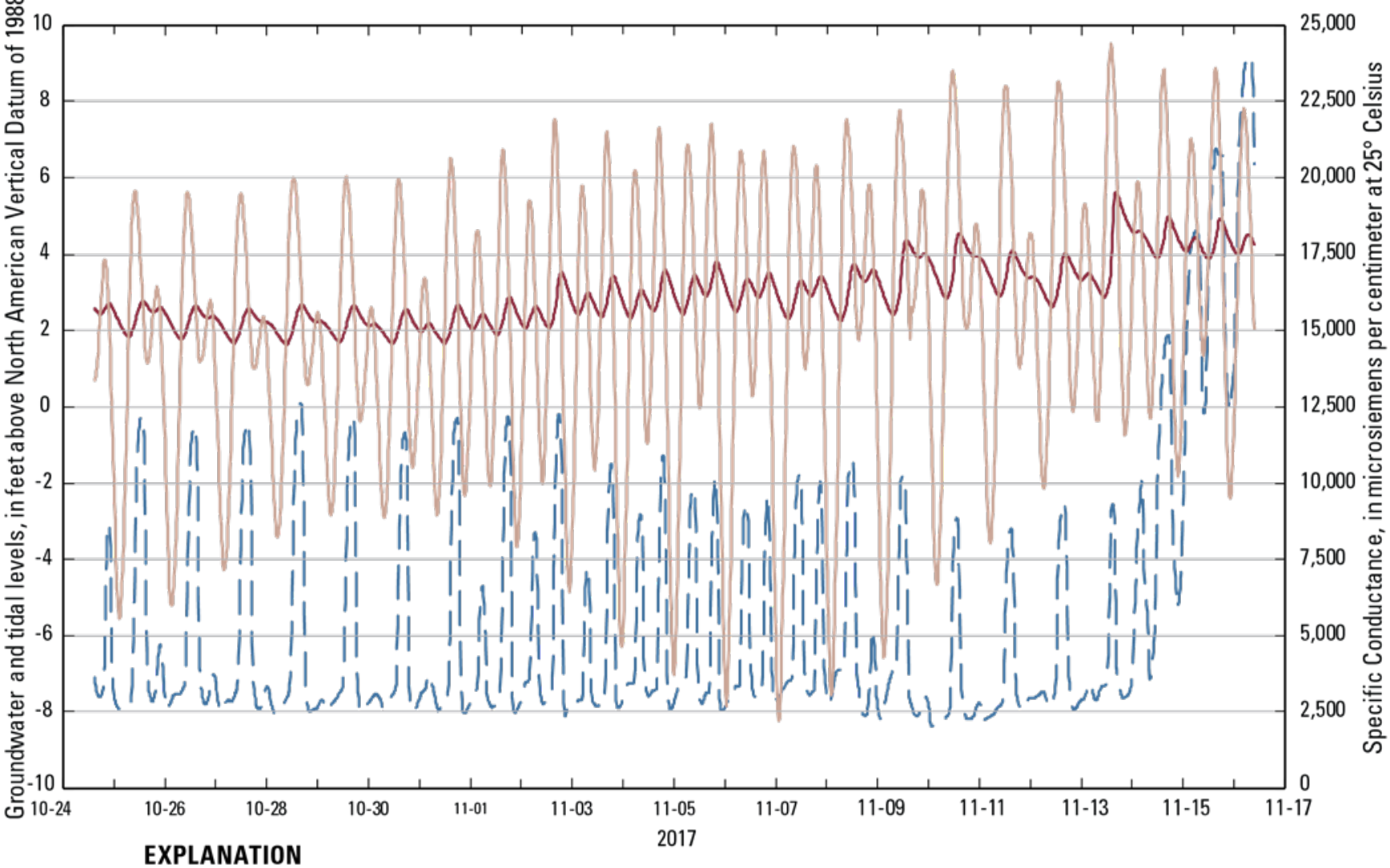

EXPLANATION

- Tidal level

_ Groundwater level

- - - Groundwater specific conductance

Figure 5. Time series of groundwater level, tidal level, and specific conductance of groundwater in shallow well MW8-12, Operable Unite 2, Area 8, Naval Base Kitsap, Keyport, Washington, October 24-November 17, 2017. 


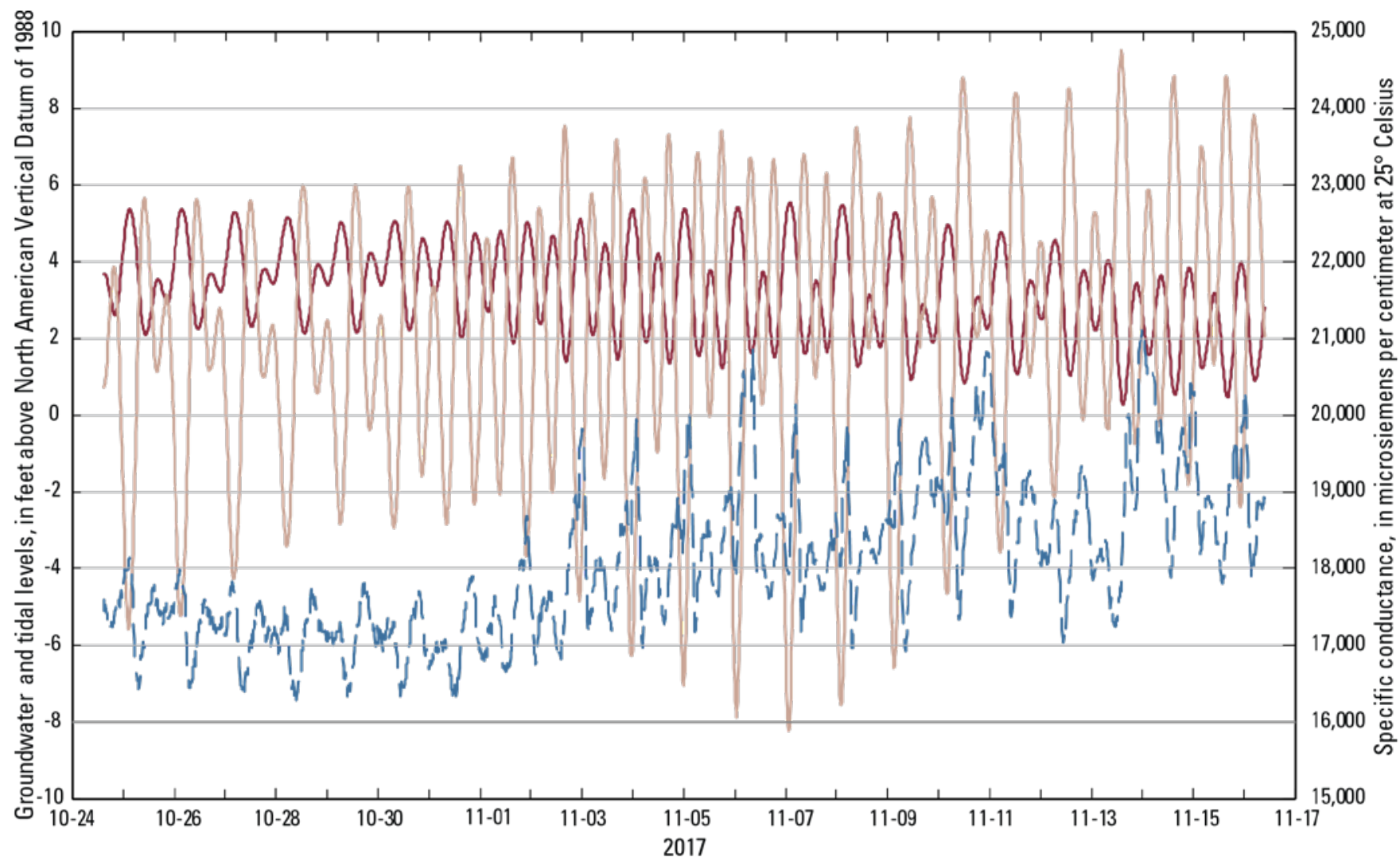

\section{EXPLANATION}

- Tidal level

— Groundwater level

- - - Groundwater spe cific conductance

Figure 6. Time series of groundwater level, tidal level, and specific conductance of groundwater in the deep well MW8-16, Operable Unit 2, Area 8, Naval Base Kitsap, Keyport, Washington, October 24-November 17, 2017. 


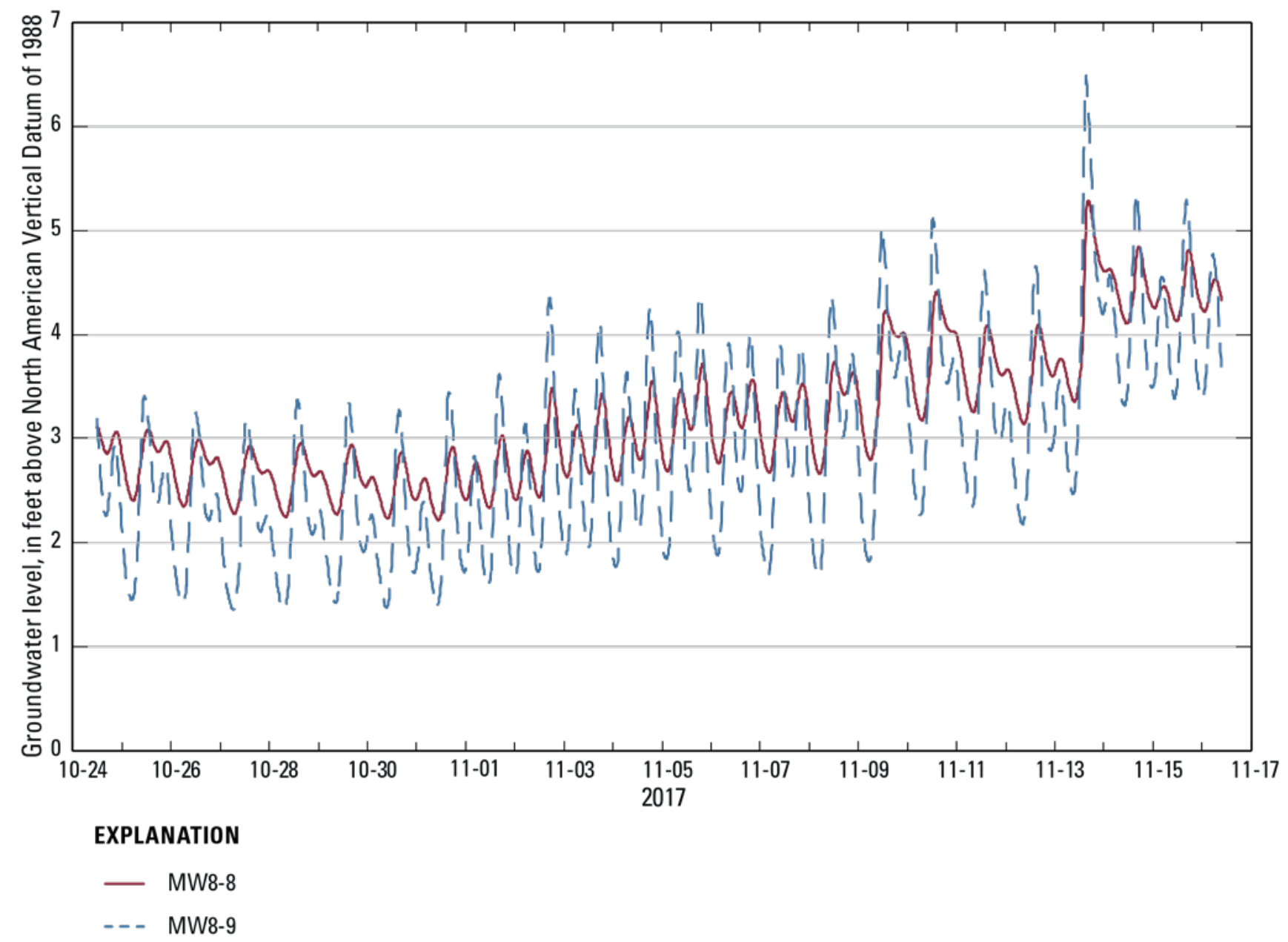

Figure 7. Differences between tides measured at the study site and tides predicted for nearby tidal reporting NOAA Station 9445719, Operable Unit 2, Area 8, Naval Base Kitsap, Keyport, Washington, October 24-November 17, 2017. 


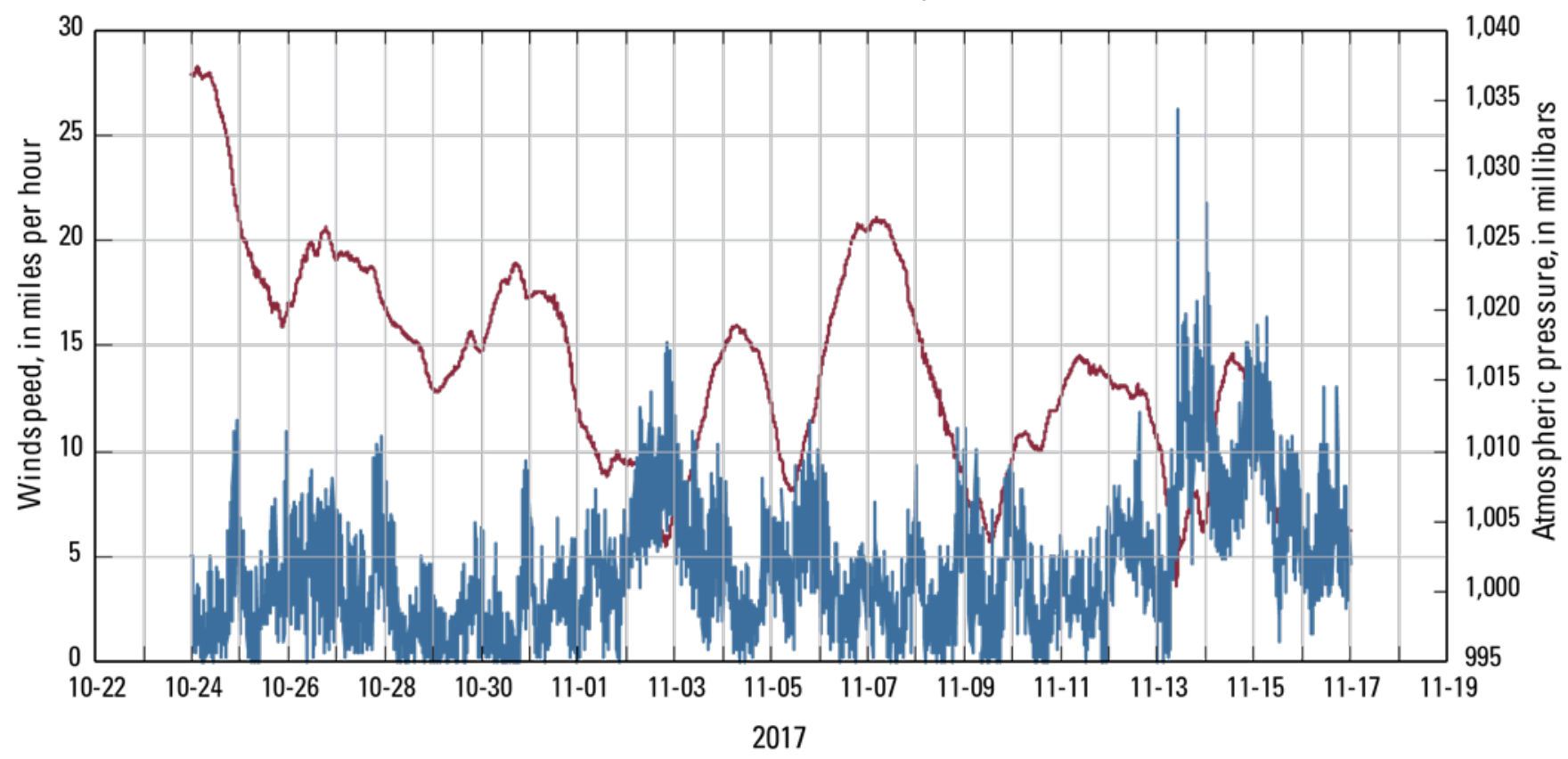

EXPLANATION

— Windspeed

— Atmospheric pressure

Figure 8. Barometric pressure and wind speeds measured at Seattle (National Weather Service Seattle Coop Station 9447130), October 24-November 17, 2017.

\section{Tidal Lag in Monitoring Wells}

The groundwater level time series data from each well, and the corresponding tidal level data (figs. 3-7), were used to calculate tidal lag times (table 5). Groundwater levels in monitoring wells, as well as tidal levels, exhibited two diurnal highs and lows throughout the entire neap to spring to neap period monitored. Each semi-diurnal low-low tidal level was followed by a low-low groundwater level in the wells. The time durations between the tidal and groundwater low-lows were calculated as the tidal lag times for each well. Over the duration of the entire time series, tidal lag times ranged from about 2 to 4.5 hours in the shallow (less-than 20-ft deep) wells screened across the water table, and from about 6 to 8 hours for the single deep (48-ft; MW8-16) well screened more than $30 \mathrm{ft}$ below the water table. 
Table 5. Ranges of lag times between the occurrence of a minimum groundwater level elevation in a monitoring well and the preceding low tide calculated from data collected October 28-November 10, 2018, at Operable Unit 2, Area 8, Naval Base Kitsap, Keyport, Washington.

\begin{tabular}{lc}
\hline $\begin{array}{c}\text { Well } \\
\text { identifier }\end{array}$ & $\begin{array}{c}\text { Range of lag times between recorded } \\
\text { minimum tide and minimum } \\
\text { groundwater levels (hours) }\end{array}$ \\
\hline MW8-8 & $2.75-3.25$ \\
MW8-9 & $2.00-2.25$ \\
MW8-11 & $3.00-3.50$ \\
MW8-12 & $4.00-4.50$ \\
MW8-14 & $2.00-3.00$ \\
MW8-16 & $6.25-8.25$ \\
\hline
\end{tabular}

Tidal lag times were substantially different between the deep well and the four shallow wells. Groundwater levels in the deep well MW8-16 were essentially a mirror image of tidal levels (fig. 6), where groundwater levels increased in concert with tidal level decreases. This groundwater level response to tides, along with exceptionally low dissolved oxygen concentrations of $0.2-3.1 \mathrm{mg} / \mathrm{L}$ (table 3), suggests well MW8-16 is completed in a different aquifer that is hydraulically disconnected from the shallow monitoring wells.

\section{Seawater Intrusion in Monitoring Wells}

The specific-conductance time-series data showed clear evidence for substantial saltwater intrusion into the screened intervals of three of the four shallow wells (MW8-8, MW8-9, and MW8-12). The intrusion was associated with the unexpectedly high tides of November 13-15, when relatively low atmospheric pressure and high southerly winds likely led to the highest tides measured during the monitoring period (figs. 3, 4 and 6). The data consistently indicated that site groundwater had the lowest specific conductance (was least mixed with seawater) during the prior neap tides around October 30. That is the same period when the shallow groundwater levels were measured at their lowest elevations. Although the response of groundwater specific conductance to tides differed between wells, collectively the data suggest that it is the actual height of the high and low tides, regardless of neap or spring tides, that allows seawater intrusion into even the most landward well (MW8-8) at Area 8 (fig. 1). The precise subsurface characteristics and processes that influence seawater intrusion into specific wells at Area 8 are not certain, particularly because of the existence of discontinuous subsurface slurry walls and similar man-made features that may affect tidal influences on nearshore groundwater. Regardless of that uncertainty, the data show that (1) the greatest proportion of seawater in shallow wells can be expected following exceptionally high tides in combination with relatively high low tides, and (2) when transient weather conditions do not overly influence tidal levels, the least proportion of seawater in shallow wells is around the time of neap tides. 


\section{Optimal Times for Groundwater Sampling}

Regarding groundwater levels, the optimal time for sampling all Area 8 wells was previously presumed to be during an approximately 2-hour-long window centered on a predicted low-low spring tide, usually during June. That is when it was assumed that freshwater would be flowing seaward unimpeded by an elevated tide. Combined analysis of the groundwater level and specific conductance data presented here instead indicates that the least proportion of seawater in shallow wells is during neap tides as long as atmospheric pressure is normal and southerly winds are not high. However, any exceptional high tide, particularly when followed by an exceptionally high low tide, can allow substantial seawater intrusion into the nearshore aquifer that could dilute contaminant concentrations in fresh groundwater. Thus, both predicted tidal levels and near-term weather forecasts should be considered when scheduling sampling of Area 8 wells.

The phenomena influencing the least proportion of seawater in shallow wells during neap tides is illustrated by the data from wells MW8-8 (landward) and MW8-9 (seaward) during the initial spring (October 23) to neap (October 30) to spring (November 6) tide transition of the monitoring period (figs. 3 and 4). Groundwater in well MW8-8 had specific conductance less than $300 \mu \mathrm{S} / \mathrm{cm}$ from October 24 until the low pressure enhanced high tide on November 13, after which the specific conductance rose on subsequent high tides to greater than 4,000 $\mu \mathrm{S} / \mathrm{cm}$. Groundwater in well MW8-9 had specific conductance that showed a pattern of being lower during the low-low neap tides and higher during the spring tides until the first measured tide of about approximately $9 \mathrm{ft}$ above NAVD88 on November 13, followed by low tides above -1 foot. In the few following days, specific conductance went from near 29,000 to over $43,000 \mu \mathrm{S} / \mathrm{cm}$, with the diurnal variation increasing substantially. These data suggest that seawater intrusion into MW8-9 increases dramatically at the tidal threshold of approximately $9 \mathrm{ft}$ above NAVD88 (corresponding to $14.7 \mathrm{ft}$ above MLLW), with associated low tides above -1 foot (corresponding to $4.7 \mathrm{ft}$ above MLLW). Groundwater-specific conductance at well MW8-12 was lowest during low-low tides a few days prior to the November 13 neap tides, and then steadily rose from less than 5,000 to greater than $24,000 \mu \mathrm{S} / \mathrm{cm}$ during the subsequent 3 days.

The hydraulic gradient between the landward and seaward wells MW8-8 and MW8-9 varied in direction and magnitude throughout the monitoring period (fig. 10). During the October 30 neap tides, the hydraulic gradient between these wells was predominately seaward, and when the gradient was landward the water level difference between wells was about 0.1 to $0.3 \mathrm{ft}$. During the period around the November 6 spring tides, the hydraulic gradient was landward during both the high-high and the lowhigh tidal levels, as opposed to only during the high-high tide level. The most substantial seawater intrusion into well MW8-8 coincides with the most substantial landward hydraulic gradient associated with the November 13 high tides. 


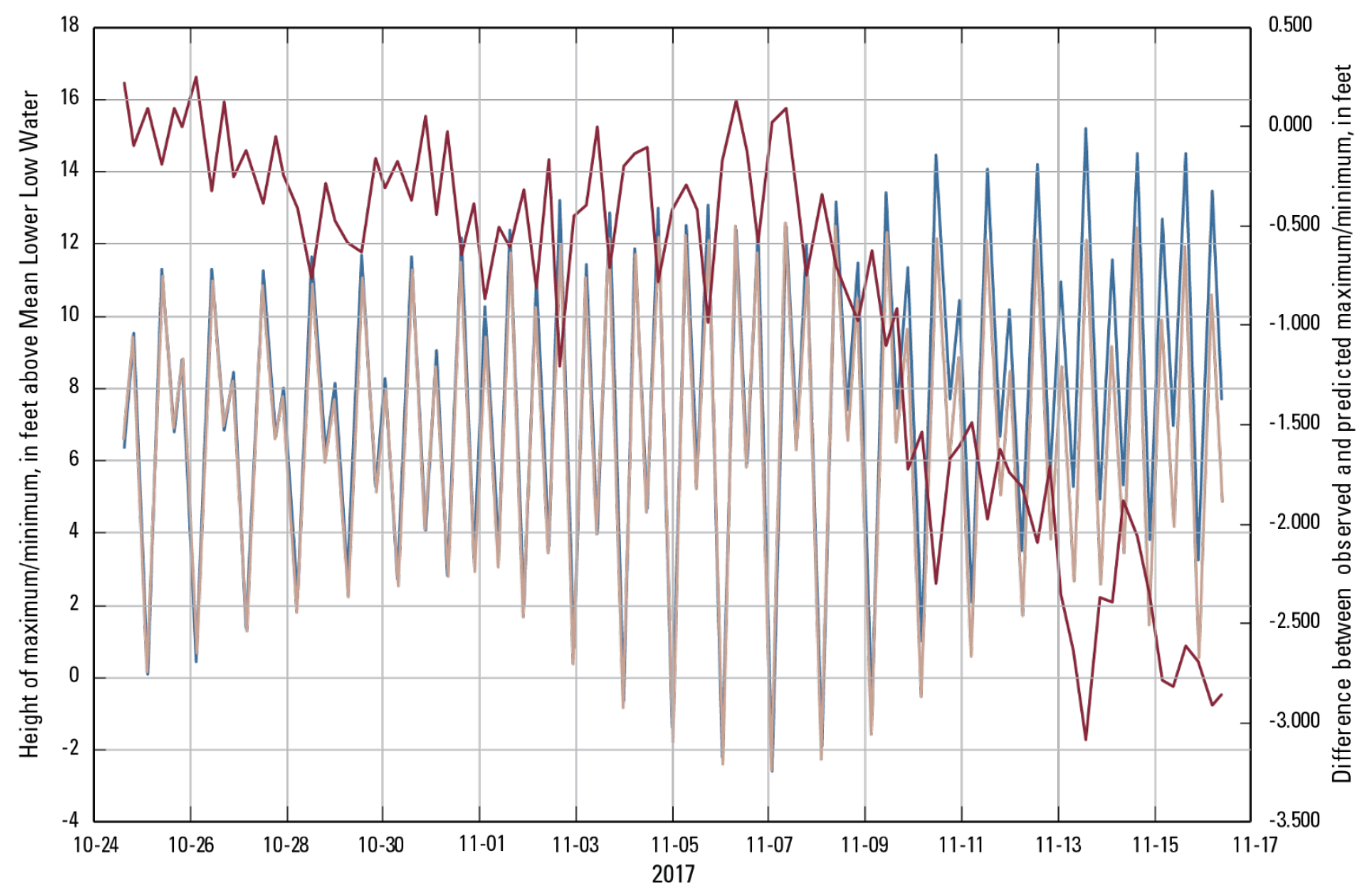

EXPLANATION

— Observed tidal level

_ Predicted tidal level

— Observed minus predicted tidal level

Figure 9. Water levels in a landward (MW8-8) and a seaward (MW8-9) well indicating direction of hydraulic gradient at Operable Unit 2, Area 8, Naval Base Kitsap, Keyport, Washington, October 24-November 17, 2017. 
With all the data taken into consideration, the optimal time for sampling the shallow monitoring wells at Area 8 would be centered on a 2-5-hour period following the predicted low-low tide during the neap tide part of the tidal cycle, with due consideration given to local atmospheric pressure and wind conditions that have the potential to generate tides that can be substantially higher than those predicted from lunar-solar tidal forces. The optimal time for sampling the deeper monitoring wells at Area 8 would be centered on a 6-8-hour period following a predicted low-low tide, also during the neap tide part of the tidal cycle. The specific time window to sample each well following a low tide can be found in table 5. Those periods are when groundwater in the wells is most fresh and least diluted by seawater intrusion. In addition to timing, consideration should be given to collecting undisturbed samples from the top of the screened interval (or top of the water table if below the top of the interval) to best characterize contaminant concentrations in freshwater. A downhole conductivity probe could be used to accurately identify the saltwater interface, above which would be the ideal depth for sampling.

\section{References Cited}

Naval Facilities Engineering Command Northwest, 2015, Fourth five-year review, Naval Base Kitsap

Keyport, Washington, final 20 November 2015: Silverdale, Washington, Department of the Navy, Naval Facilities Engineering Command Northwest.

National Oceanic and Atmospheric Administration, 2018, Tides and currents-Datums for 9445719, Poulsbo, Washington: National Oceanic and Atmospheric Administration, web, accessed March 9, 2018, at https://tidesandcurrents.noaa.gov/datums.html?id=9445719.

U.S. Navy, U.S. Environmental Protection Agency, and Washington State Department of Ecology, 1994, Superfund record of decision for Operable Unit 2, Naval Undersea Warfare Center, Division Operable Unit 2, Keyport, Washington: Silverdale, Washington, URS Consultants, Inc., and Science Applications International Corporation, Prepared for Engineering Field Activity, Northwest, Western Division, Naval Facilities Engineering Command, under Comprehensive Long-Term Environmental Action Navy (CLEAN) Northwest Area, Contract No. N62474-89-D-9295, CTO 10. 
Publishing support provided by the U.S. Geological Survey

Science Publishing Network, Tacoma Publishing Service Center

For more information concerning the research in this report, contact the Director, Washington Water Science Center

U.S. Geological Survey

934 Broadway, Suite 300

Tacoma, Washington 98402

https://wa.water.usgs.gov 
